\title{
VISUAL THINKING: ENHANCING ART CRITICISM SKILLS AMONG SPATIAL LEARNERS
}

\author{
Harrinni Md Noor ${ }^{1 *}$ Zarina Samsudin $^{2}$ \\ ${ }^{1}$ Dr., Faculty of Education, Universiti Teknologi MARA, Selangor, Malaysia. \\ harrinni@salam.uitm.edu.my \\ ${ }^{2}$ Assoc. Prof. Dr., Centre of Instructional Technology and Multimedia, Universiti Sains Malaysia, \\ Penang, Malaysia. ina@usm.my \\ ${ }^{*}$ Corresponding author
}

\begin{abstract}
Art criticism is one of the four foundational disciplines of Discipline-based Art Education (DBAE). It refers to an organized system for studying the work of art by looking and talking about art that involves making description, analysis, interpretation and judgments about artworks. However, most of the times, students do not know what to say, or how to go about saying it, or they might make the wrong judgments. Art students are mostly visual-spatial learners. Very often these students also end up writing in a dull way, with little sense of academic values. Therefore, visual imageries play an important role for these spatial learners who are skilful in representing, transforming, generating, and recalling symbolic, non-linguistic information. In the 21st century, teaching and learning with technology have diversified to complement the age of digital era where technology is made available to cater for all learning styles.
\end{abstract}

A Visual Thinking Courseware (VTC) was designed and developed to help solve the problem of teaching Art Education by introducing systematic strategies particularly on visuals to enhance students' Art Criticism skills. Built on Gestalt Theory, the objective of this research was to determine the best visual selections for the teaching and learning of Art Criticism between Random Visual Selection (RVS) and Sequenced Visual Selection (SVS). Research was carried out to determine the difference in students' performance in Art Criticism between High Spatial Learners (HSL) and Low Spatial Learners (LSL) using these RVS and SVS modes.

The methodology used in this research was quantitative and qualitative in nature. A quasi-experimental design was applied to collect the necessary data. A pretest and posttest for the two treatment groups was implemented. Six research instruments were used in the research to obtain the data namely, Index for learning Styles Questionnaire (ILSQ), Spatial Ability Test, Pretest and Posttest, Courseware Evaluation Form, Art Criticism Rubrics and Critical Thinking Rubrics. Sixty-three post degree education diploma students participated in this study. This research indicates that there are significant difference in students' performance in Art Criticism skills between High Spatial Learners (HSL) and Low Spatial Learners (LSL) using RVS and SVS. 
Data analysis showed that among HSL students, the RVS mode helped them to improve Art Criticism skills better than the SVS mode. For the LSL students, the SVS mode helped them to improve their Art Criticism skills better than the RVS mode. Therefore, it can be concluded that regardless of the visual selections, Visual Thinking Courseware used in this research enabled students to criticize better and help improve their Art Criticism skills.

\section{Keywords: Visual Thinking, Spatial Ability, Art Criticism, Art Education}

\section{INTRODUCTION}

Art criticism provides an organized system for studying the work of art by looking and talking about art. It helps to foster critical thinking and facilitates one's ability to describe, interpret and judge art. Currently Feldman's (1973) four sequential steps of 'Description, Analysis, Interpretation and Judgment' have been used for Art Criticism purposes in many Art Education classes. This model is considered as a formal criticism method held in the highest esteem in the Discipline-based Art Education (DBAE) scheme (Mathews, 2007). This model guides students from concrete details to abstract concepts, from knowledge, comprehension, analysis and evaluation.

However, using a good model to critically analyse artworks is not enough. There is a need for more specific instructional guidelines if Art Criticism is to be widely implemented (Hamblem, 1984). Furthermore, the formulation of Art Criticism questions will help promote student's interest and the development of analytical skills. For beginning viewers, it should be a thoughtful process and there should be ways to capture and sustain their interests.

Criticizing artwork often involves two complimentary thinking activities: creative thinking to produce ideas and critical thinking to evaluate them. These elements are evident in Gestalt Theory that attempts to describe how people tend to organize visual elements into groups or unified wholes when certain principles are applied. The involvement of visual perception and the psychology of art in Gestalt Theory of Perception and Visual Thinking (Arnheim, 1969), is related to the area of Art Criticism as it includes in the making of interpretation and judgment on a piece of artwork. These also includes discovery learning (Hamblem, 1984), critical knowledge (Culp, 2015; Caroll, 2002) and problem solving (Nilson, Fetherston and McMurray, 2013) which are the general goals in art education and should be emphasized in Art Criticism.

Therefore, Visual Thinking Courseware (VTC) was designed and developed in this research to help in the teaching and learning of Art Criticism. VTC was designed to assist in the instruction by incorporating a more systematic approach to the teaching and learning of Art Criticism. The framework could accommodate the details and sequences of the practice of skills. It comprised of different levels of thinking (Bell, 2012) and also a teaching methodology within the stages of art criticism (Barret, 2010).

The visual selections suggested by Yenawine (2003) and Housen's Visual Thinking Strategies (VTS) (2000) were also applied in the courseware to help undergraduates of Art and Design Education to grasp the skills before they go out to teach in schools. There are two modes of VTC. The first is Sequenced Visual Selection (SVS) that uses visual materials that are sequenced from the simpler to more complex visuals in terms of subject-matter and composition. For example, in this research, students go through the art criticism stages by answering questions from the simpler visuals first and later moved on to more complex visuals. The second mode is Random Visual Selection (RVS) that uses visual materials that are randomly arranged. For example, in this research, visuals used for the art criticism purposes are not arranged in any order of complexity. At every stage of the tasks, visuals are randomly put with a mix of simple and complex visuals.

Therefore, the objectives of this research were:

1. To find out the difference in students' performance in art criticism between High Spatial Learners (HSL) and Low Spatial Learners (LSL) using two different visual selection modes - Random Visual Selection (RVS) and Sequenced Visual Selection (SVS).

2. To find out the difference in students' performance in art criticism among High Spatial Learners (HSL) and Low Spatial Learners (LSL) using the same visual selection modes (RVS and SVS).

The research questions in this study were:

1. Does students' performance in art criticism differ among High Spatial Learners (HSL) in using RVS and SVS modes?

2. Does students' performance in art criticism differ among Low Spatial Learners (LSL) in using RVS and SVS modes? 
3. Does students' performance in art criticism differ among High Spatial Learners (HSL) and Low Spatial Learners (LSL) who uses RVS mode?

4. Does the students' performance in art criticism differ among High Spatial Learners (HSL) and Low Spatial Learners (LSL) who uses SVS mode?

5. Do the two different visual modes allow students to criticise better?

\section{METHOD}

A web-based courseware was designed and developed based on the Thinking Theory (Arnheim, 1969; Housen \& Yenawine, 2002) and using Gagne Nine Events of Instructions (Gagne, Briggs \& Wagner, 1992) as well as model for design and development developed by Alessi and Trollip (2001). A pilot test was carried out on a first draft or prototype of the courseware for purpose of formative evaluation before the actual research was conducted. This courseware was pilot tested among 10 students and three subject matter experts (SME). These experts had more than 20 years of experience each in the teaching and learning of art in education. They are currently active in research in the areas of Art Education including Art Criticism and aesthetics. Their expertise helped verify the contents and materials used for this courseware that best suit the Malaysian undergraduate students. They evaluated the courseware in terms of its technical, curriculum and cosmetic adequacies and inadequacies. Improvements and upgrading was made based on the formative evaluation. The final version was verified by experts before it was used in the actual research.

The samples are post degree education diploma students, who viewed the courseware and followed the activities and assignments provided during the seven weeks period. A pretest was administered before they were allowed to go through the treatment process. A posttest was administered at the end of the treatment. Students' pre and post test scores were taken as an indicator of their achievements in using the two modes of courseware.

The quantitative data was collected in the pretest and posttest as the summative evaluation. Students' written scripts from the tests were analyzed to gain insight on the effects of the VTC on their art criticism skills.

\section{POPULATION AND SAMPLES}

The samples consisted of 63 students who underwent post degree education diploma in Art and Design Education field. They took the post degree education diploma after completing a degree to enable them to teach in public schools. These samples had undergone the basic training in art and design that is the prerequisite to follow through the art criticism framework. At this level, they have undergone basic training to understand and apply the knowledge on Elements and Principles of Art to carry out a critical analysis of an art work. All the students had an entry qualification of Malaysian University English Test (MUET) with Band 2 or 3 which help clarifies the mode of instructions which is English. The sample was divided into two groups, High Spatial Learners (HSL) and Low Spatial Learners (LSL) that are determined by the Spatial Ability Test and the Index for Learning Styles Questionnaire (ILSQ). They are then divided into two groups that represented the two modes that were used in the research - Random Visual Selection (RVS) and Sequenced Visual Selection (SVS). The names of the students were randomly selected based on the alphabetical name listing provided by the faculty.

\section{RESEARCH DESIGN}

The methodology used in this research was quantitative and qualitative in nature. The quantitative data shed some light on the research questions. The qualitative data provided the research with an in-depth view of the strength and weaknesses of the courseware. Students' opinion and suggestions were also obtained from the qualitative data. It is the aimed of this research to find out if there is any significant difference in students' achievements between students who use Random Visual Selection (RVS) and those using Sequence Visual Selection (SVC). This research also aimed to find out if there was any significant difference in students' achievements with different learning styles in using the two different visual selection modes. The research was also carried out to find out the effectiveness of the visual strategies in the Art Criticism courseware.

Therefore, a quasi-experimental design was applied. A pretest and posttest for the two treatment groups was implemented. Pretest was administered to the two groups in the form of a sixty-minute written test. Treatment was then given to all experimental groups within the duration of three weeks in which the viewing time for the courseware would be completed. The posttest took place at the end of the treatment in the form of a sixty-minute written test. 


\section{RESEARCH INSTRUMENTS}

The following research instruments were used in the research to obtain the data.

\subsection{Index of Learning Style Questionnaire (ILSQ)}

The Index of learning Style Questionnaire (ILSQ) that was used in this study was formulated by Richard M. Felder and Linda K. Silverman in 1991 (Felder, 1993). It is an instrument used to measure the four dimensions of learning style model that includes the verbal/visual learning styles. This questionnaire was used in this study to determine the students learning style, whether they were visual or verbal learners. The questionnaire was administered at the start of the study.

\subsection{Spatial Ability Test}

The Spatial Ability Test by Newton and Bristol (2009) was used in this study to determine students' spatial ability. Based on the score, the students were divided into two groups, the High Visual Learners (HVL) and the Low Visual learners (LVL) based on their scores. There were 45 items in this test and students were required to complete them in 20 minutes.

Questions in the test contain series of pictorial figures rather than words or numbers. It does not involve analysis and reasoning. It is purely a test of mental manipulation. Students had to look for the logical relationship between figures. They had to try and form mental images and visualize movement or change between them. It contained numerous types of question students are likely to encounter - including shape matching, group rotation, combining shapes, cube views in three dimensions, other solids in 2 and 3 dimensions, and maps and plans.

The spatial ability questions in the test involved the visual assembly and the disassembly of objects that have been rotated, which are viewed from different angles or objects that have different markings on their surfaces. Students were challenged to answer them all in the time allocated. This test looked at students' ability to think visually and solve spatial problems in two and three dimensions.

\subsection{Pretest and Posttest}

A set of sixty-minute written test was administered to assess students' critical thinking skills during the pretest and posttest. Questions were set according to standard examination format for the Art and Design Education Program at the Faculty of Education, UiTM. There were two questions in each test. The first question required students to write a critical analysis of the work of art seen in the picture. They were required to describe, analyze, interpret and then make a final judgment of the work. The second question required the students to discuss the similarities and differences of the two artworks in the picture. They were needed to also describe at least three elements of designs used by the two artists to communicate their purpose.

Both the pretest and posttest questions were of the same level of difficulty with similar visual themes. The content validity of the tests was judged by a panel of SMEs who are knowledgeable about the materials, the format and the wording of the instrument, and the content validity of each item.

The Holistic Critical Thinking Rubrics for Art Criticism were used to assess students' performance in the tests. The score were then used to indicate their performance.

\subsection{Art Criticism Rubrics}

The Art Criticism Rubrics used in this study was developed by Bartel (2001-2007) for the discussions and writing of Art Criticism. It provides 16 levels of scoring that follows the four stages of Art Criticism (Description, Analysis, Interpretation and Judgment). This rubric focuses on the discussions and writing. Therefore, the rubrics were suitable to grade the students' score in the test as they would be discussing the answers in writing.

\section{DATA ANALYSIS}

All the experimental groups completed both the pretest and posttest within the six-week duration. Both the tests, in the form of one-hour written test was analyzed and graded by the researcher. The scores were moderated by another lecturer. The t-test for paired samples was used to compare the single group's performance on the pretest and posttest between which the treatment was given. This is also to determine any significant differences in the scores among the two groups (HVL and LVL) on the two instructional modes used in the research (RVS and SVS). 
SPSS was used to process the descriptive statistical data of mean score in students' performance. The t-test was used to examine the effects between the two modes of instructional strategies and the learning styles.

\section{RESULTS AND FINDINGS}

Students were divided into two groups - the High Spatial Learners (HSL) and the Low Spatial Learners (LSL). There were 22 students in the HSL group (50.8\%) and 21 (49.2\%) students in the LSL group. The students were further divided into two groups using two different visual selection modes (RVS and SVS). Therefore, there were four different treatment groups.

Table 1 shows there were 17 (27\%) students in HSL group who used Random Visual Selection (RVS) mode and $15(23.8 \%)$ students in HSL group who used Sequenced Visual Selection (SVS) mode. Sixteen (25.4\%) students in the LSL group were given the RVS mode and the remainder $15(23.8 \%)$ students in the LSL group were given the SVS mode.

Table 1. The 4 treatment groups

\begin{tabular}{|c|r|r|r|r|r|}
\hline \multicolumn{1}{|c|}{} & Frequency & Percent & Valid Percent & $\begin{array}{c}\text { Cumulative } \\
\text { Percent }\end{array}$ \\
\hline Valid & HSL/RVS & 17 & 27.0 & 27.0 & 27.0 \\
\cline { 2 - 6 } & HSL/SVS & 15 & 23.8 & 23.8 & 50.8 \\
\cline { 3 - 6 } & LSL/RVS & 16 & 25.4 & 25.4 & 76.2 \\
\cline { 3 - 6 } & LSL/SVS & 15 & 23.8 & 23.8 & 100.0 \\
& Total & 63 & 100.0 & 100.0 & \\
\hline
\end{tabular}

The results in Table 2 indicate that there is a difference in mean before and after using the courseware. Mean for pretest was $m=10.23$ and after using the courseware their mean score increased to $m=19.3$. There is an increase of 9.7 marks before and after using the courseware. It is also found that there is a significant difference between pre and posttest scores with $t$-value at $11.39, \mathrm{df}=16$ and significant value of $\mathrm{p}=0.00$. This would indicate that the courseware helped improved HSL group's Art Criticism skills as seen by the increase of mean score and t-test among the students when using the RVS mode. Therefore, given the significant value of $p \leq 0.05$ it can be concluded that there is a significant difference in students' performance in Art Criticism skills among High Spatial Learners in using RVS mode.

Table 2. Results of HSL performance in using the RVS mode

\begin{tabular}{|c|c|c|c|c|c|c|}
\hline & & Mean & $\mathrm{N}$ & $\mathrm{t}$ & $\mathrm{df}$ & Sig. (2-tailed) \\
\hline Pair 1 & $\begin{array}{c}\text { Art Criticism } \\
\text { Pretest }\end{array}$ & 10.2353 & 17 & -11.392 & 16 & .000 \\
\hline $\begin{array}{c}\text { Art Criticism } \\
\text { Posttest }\end{array}$ & 19.3235 & 17 & & & \\
\hline
\end{tabular}

Significant level at $\mathrm{p} \leq 0.05$

The results in Table 3 show that mean score prior to using the courseware was mean $=10.93$ and after using the courseware was mean $=19.73$. This indicates that there is a difference in mean before and after using the courseware. There is an increase of 8.8 points before and after using the courseware.

It is also found that there is a significant difference between pre and posttest scores with $t$ value at 6.08 , $\mathrm{df}=14$ and significant value of $\mathrm{p}=0.00$. This would indicate that the courseware helped improved HSL group's Art Criticism skills as seen by the increase of mean score among the students when using the RVS mode. Therefore, at the significant value of $p \leq 0.05$ there is a significant difference in students' performance among the High Spatial Learners in using SVS mode. 
Table 3. Results of HSL performance in using the SVS mode

\begin{tabular}{|c|c|c|c|c|c|c|}
\hline & & Mean & $\mathrm{N}$ & $\mathrm{t}$ & $\mathrm{df}$ & Sig. (2-tailed) \\
\hline Pair & Art Criticism Pretest & 10.9333 & 15 & -6.087 & 14 & .000 \\
\hline & Art Criticism Posttest & 19.7333 & 15 & & & \\
\hline
\end{tabular}

Significant level at $p \leq 0.05$

The results in Table 4 an increase of mean score among the students when using the RVS mode. Their mean score prior to using the courseware was mean $=10.25$ and after using the courseware their test score increased to mean $=17.84$. There is an increase of 7.59 points before and after using the courseware. This would indicate that the courseware helped improved LSL group's Art Criticism skills as seen by the increase of mean score and t-test among the students when using the RVS mode.

The results also indicate that the difference between pre and posttest scores was significant with $t$ value at 7.66 with $\mathrm{df}=15$ and significant value of $p=0.00$. Therefore, at the significant value of $p \leq 0.05$ there is a significant difference in students' performance among the Low Spatial Learners in using RVS mode.

Table 4. Results of LSL performance in using the RVS mode

\begin{tabular}{|l|l|c|c|c|c|c|}
\hline & & Mean & $\mathrm{N}$ & $\mathrm{t}$ & $\mathrm{df}$ & Sig. (2-tailed) \\
\hline \multirow{3}{*}{ Pair 1 } & Art Criticism Pretest & 10.2500 & 16 & -7.664 & 15 & .000 \\
\cline { 2 - 7 } & Art Criticism Posttest & 17.8438 & 16 & & & \\
\hline
\end{tabular}

Significant level at $p \leq 0.05$

The results in Table 5 indicate there is a difference in mean before and after using the courseware. Their mean score prior to using the courseware was Mean=7.2 and after using the courseware their test score increased to Mean=18.03. There is an increase of 10.83 points before and after using the courseware. It is also found that there is a significant difference between pre and posttest scores with t-value at 13.37 with $\mathrm{df}=14$ and significant value of $p=0.00$. This would indicate that the courseware helped improved LSL group's Art Criticism skills as seen by the increase of mean score and t-test among the students when using the SVS mode.

Therefore, given the significant value of $p \leq 0.05$ it can be concluded that there is a significant difference in students' performance in Art Criticism skills among Low Spatial Learners (LSL) in using SVS mode.

Table 5. Results of LSL performance in using the SVS mode

\begin{tabular}{ccccccc}
\hline & & Mean & $\mathrm{N}$ & $\mathrm{t}$ & $\mathrm{df}$ & Sig. (2-tailed) \\
\hline Pair 1 & Art Criticism Pretest & 7.2000 & 15 & -13.372 & 14 & .000 \\
& Art Criticism Posttest & 18.0333 & 15 & & & \\
\hline
\end{tabular}

Significant level at $p \leq 0.05$

The results in Table 6 show that HSL group of students have slightly lower mean score with mean=10.23 as compared to the LSL group with mean $=10.25$ in the pretest score using RVS mode. There is a difference of 0.02 marks. However, it is found that there is no significant difference between HSL and LSL pretest scores with $t$-value at .013 with $\mathrm{df}=31$ and significant value of $p=0.99$. This would indicate that the Art Criticism skills among the two groups before using the courseware are almost similar.

Therefore, given the significant value of $p \leq 0.05$ it can be concluded that there is no significant difference in students' pretest performance in Art Criticism skills among High Spatial Learners (HSL) and Low Spatial Learners (LSL) in using SVS mode. 
Table 6. Results of HSL and LSL Pretest performance in using the RVS mode

\begin{tabular}{|c|c|c|c|c|c|c|}
\hline & Group & $\mathbf{N}$ & Mean & $\mathbf{t}$ & $\mathbf{d f}$ & $\begin{array}{c}\text { Sig. (2- } \\
\text { tailed) }\end{array}$ \\
\hline $\begin{array}{c}\text { Art Criticism } \\
\text { Pretest }\end{array}$ & HSL/RVS & 17 & 10.2353 & -.013 & 31 & .990 \\
\cline { 2 - 6 } & LSL/RVS & 16 & 10.2500 & & & \\
\hline
\end{tabular}

Significant level at $p \leq 0.05$

The results in Table 7 show that HSL group of students have slightly higher mean score with mean=19.32 as compared to the LSL group with mean=17.84 in the posttest score using RVS mode. There is a difference of 1.48 marks. However, it is found that there is no significant difference between HSL and LSL posttest scores with $\mathrm{t}$-value at 1.37 with $\mathrm{df}=31$ and significant value of $\mathrm{p}=018$. This would indicate that the Art Criticism skills among the two groups before after using the courseware are almost similar.

Therefore, given the significant value of $p \leq 0.05$ it can be concluded that there is no significant difference in students' pretest and posttest performance in Art Criticism skills among High Spatial Learners (HSL) and Low Spatial Learners (LSL) in using SVS mode.

Table 7. Results of HSL and LSL Posttest performance in using the RVS mode

\begin{tabular}{|c|c|c|c|c|c|c|}
\hline & Group & $\mathbf{N}$ & Mean & $\mathbf{t}$ & $\mathbf{d f}$ & Sig. (2-tailed) \\
\hline $\begin{array}{c}\text { Art Criticism } \\
\text { Posttest }\end{array}$ & HSL/RVS & 17 & 19.3235 & 1.372 & 31 & .180 \\
\cline { 2 - 7 } & LSL/RVS & 16 & 17.8438 & & & \\
\hline
\end{tabular}

Significant level at $p \leq 0.05$

The results in Table 8 show that there is a difference in mean score prior to using RVS courseware in the pretest among VSL and HSL. HSL group of students have higher means at mean=10.93 compared to the LSL group with mean=7.2. There is a difference of 3.73 marks. It is also found that there is a significant difference between HSL and LSL pretest scores with $\mathrm{t}$-value at 3.58 with $\mathrm{df}=28$ and significant value of $p=0.001$. This would indicate that HSL group significantly has higher level of Art Criticism skills compared to the LSL group before using SVS mode.

Therefore, given the significant value of $p \leq 0.05$ it can be concluded that there is a significant difference in students' pretest performance in Art Criticism skills among High Spatial Learners (HSL) and Low Spatial Learners (LSL) prior to using SVS mode.

Table 8. Results of HSL and LSL Pretest performance in using the SVS mode

\begin{tabular}{|c|c|c|c|c|c|c|}
\hline & Group & $\mathrm{N}$ & Mean & $\mathrm{t}$ & $\mathrm{df}$ & Sig. (2-tailed) \\
\hline $\begin{array}{c}\text { Art Criticism } \\
\text { Pretest }\end{array}$ & HSL/SVS & 15 & 10.9333 & 3.588 & 28 & .001 \\
\cline { 2 - 7 } & LSL/SVS & 15 & 7.2000 & & & \\
\hline
\end{tabular}

Significant level at $p \leq 0.05$

On the other hand, the results in Table 9 show that there is a difference in mean score prior to using RVS courseware in the pretest among VSL and HSL. HSL group of students have higher means at mean=10.93 compared to the LSL group with mean=7.2. There is a difference of 3.73 marks. It is also found that there is a significant difference between HSL and LSL pretest scores with t-value at 3.58 with $\mathrm{df}=28$ and significant value of $p=0.001$. This would indicate that HSL group significantly has higher level of Art Criticism skills compared to the LSL group before using SVS mode.

Therefore, given the significant value of $p \leq 0.05$ it can be concluded that there is a significant difference in students' pretest performance in Art Criticism skills among High Spatial Learners (HSL) and Low Spatial Learners (LSL) prior to using SVS mode. 
Table 9. Results of HSL and LSL Posttest performance in using the SVS mode

\begin{tabular}{|c|c|c|c|c|c|c|}
\hline & Group & $\mathrm{N}$ & Mean & $\mathrm{t}$ & $\mathrm{df}$ & Sig. (2-tailed) \\
\hline $\begin{array}{c}\text { Art Criticism } \\
\text { Posttest }\end{array}$ & HSL/SVS & 15 & 19.7333 & 1.304 & 28 & .203 \\
& LSL/SVS & 15 & 18.0333 & & & \\
\hline
\end{tabular}

Significant level at $\mathrm{p} \leq 0.05$

\section{DISCUSSION}

The main aim of the research was to find out the significant difference in students' performance in art criticism among High Spatial Learner (HSL) and Low Spatial Learner (LSL) when using two modes of Visual Thinking Courseware, Random Visual Selection (RVS) and Sequenced Visual Selection (SVS).

Data analysis found that there is a significant difference in students' performance in Art Criticism among the High Spatial Learners (HSL) in using both RVS and SVS mode. Students score increased after using both modes. However, based on the mean score, HSL showed more improvement when using the RVS mode as compared to the SVS. This would indicate that the courseware helped improved HSL group's Art Criticism skills as seen by the increase of mean score among the students when using any of the two modes.

Regardless of the visual selections, the systematic approach to teaching students to criticize works of art in the courseware, indeed helped the HSL group to improve their Art Criticism skills. The four stages implemented in the courseware - Description, Analysis, Interpretation and Judgment allowed students to make intelligent judgments. As stated by Ragans (2000) when we take the time to look at a work of art and then describe, analyse and interpret what we think the meaning would be, our judgments becomes clearer and more intelligent. According to Feldman (1970) the four stages are able to guide students from concrete details to abstract concepts, from knowledge and comprehension to analysis to evaluation. This would allow the students to closely follow the steps during Art Criticism activity.

There is also an increase of mean score among the LSL group when using the RVS and SVS mode. Students show an increase in their mean score after using the two modes of courseware. However, LSL group scored better in their score when using RVS as compared to SVS.

This indicates that for LSL, using RVS would help improve their Art Criticism skills better. This could be due to the fact that in RVS, visuals were not arranged in any order of complexity, with a mix of simple and complex visuals. Arranging visuals in random order allowed students to constantly attempt at mastering their Art Criticism skills, at every step of the way. Thus, making it easier for them to analyse the simpler ones after getting over the basics of analysing the difficult visuals.

HSL and LSL have same Art Criticism level before using the RVS mode. There was no significant difference in their pretest score. There is an increase in the posttest score for both HVL and LVL. However, the score was not significant. Therefore, it can be concluded that RVS is suitable for both HVL and LVL group. RVS mode was able to improve their Art Criticism skills regardless of their spatial ability.

HSL scored higher in both scores before and after using the courseware as compared to LSL. However, after using the courseware the difference in the mean score for both HSL and LSL are not significant. Although HSL started at a higher Art Criticism skill, after using the courseware, the level of Art Criticism was almost similar to the LSL.

Therefore, it can be concluded that HSL has higher score than LSL in using SVS mode but the difference in score was not significant. Perhaps, this could be due to the nature of the activities that required students to make a critical analysis through writing task. This process requires flare in writing. The fact that their MUET score was at the average of Band 3 we could assume that their writing ability was almost at par with each other. Therefore, the skills in writing also play a major role in students' performance in Art Criticism. If the activity requires writing skills, the visuals or spatial ability do not have a huge impact on students' Art Criticism skills.

Thus, in this research, SVS allows students to improve their Art Criticism skills whether they are HSL or LSL. However, writing skills could influence their performance in Art Criticism when using the courseware. For HSL, RVS helped them to improve Art Criticism skills better than SVS. For LSL, SVS helped them to improve their Art Criticism skills better than RVS. 
Therefore, it can be concluded that the two visual modes allowed students to criticize better. Based on the qualitative analysis of the research, majority of students stated that the courseware was good for Art Criticism activities. It is easy to use and also user-friendly.

\section{CONCLUSION}

Results of the research showed that the two modes of visual selection - Random Visual Selection and Sequenced Visual Selection had an impact on students' performance in Art Criticism. Data analysis showed positive improvements in their art criticism skills while using both modes. High Spatial Learners showed more improvements in their score when using the Random Visual Selection while Low Spatial Leaners scored better in their tests when using the Random Visual Selection. However, when using both Random Visual Selection and Sequenced Visual Selection modes, High Spatial Leaners scored higher than the Low Spatial Leaners.

Therefore, it is timely that a courseware like Visual Thinking Courseware (VTC) is included in Art Education. Art educators should find time to practice Art Criticism. Higher learning institutions that offer courses in art related areas should consider using the courseware to help their students in Art Criticism. This courseware allows viewers to respond, interpret and make critical judgments on specific works of art either in verbal or written form. The web-based courseware would also enable students to use it at any point of time and could fit into the course schedule at any time within the semester. Teachers and students will have easy access to the web-based materials. Teacher training institutions could also use this courseware to help provide the knowledge and training for undergraduate students in Art Criticism to contribute with the creation, understanding, and appreciation of art.

In line with UNESCO declarations that art is used in education through Arts in Education (AiE) approach, using this courseware in art education would not only improve on children and adolescents' art criticism skills but also have an impact on their intellectual and personal development. It can be introduced as an addition to conventional teaching methods. It is also time and cost effective.

According to Wagner (2005) art is needed as a subject as well as a tool and methodology. Therefore, the courseware is relevant indeed as it has an art approach that could help promote Art Criticism among students, along with cognitive development and academic achievement. This attempt would be good for Malaysia who has actively supported UNESCO's initiatives and all geared towards making Art Education part of the $21^{\text {st }}$ century agenda.

\section{ACKNOWLEDGEMENT}

The authors would like to thank Universiti Teknologi MARA and Universiti Sains Malaysia for supporting this study at the doctoral research level.

\section{REFERENCE LIST}

Alessi, S. and Trollip, S. (2001). Multimedia for Learing. Massachusetts: Alyn and Bacon.

Arnheim, R. (1969). Visual Thinking. Berkeley, CA: University of California Press.

Atherton J. S. (2011) Learning and Teaching; Gestalt and learning [On-line: UK] retrieved 27 June 2013 from http://www.learningandteaching.info/learning/gestalt.htm

Barrett, T. (2003). Art: Reflecting, Wondering and Responding. New York: McGraw-Hill.

Barrett, T. (2010). Making Art: Form and meaning. New York: Mc Graw Hill.

Caroll (2002). Cultivating the Critical Mind. Journal of Art and Design Education. 21(1). 60-70.

Culp, M. (2015). Diving into the Creative Realm. Journal of the National Art Education Association. 68(3). 610.

Gagne, R., Briggs, L. \& Wager, W. (1992). Principles of Instructional Design (4th Ed.). Fort Worth, TX: HBJ College Publishers.

Hamblem, K. (1984). An Art Criticism Questioning Strategy within the Framework of Bloom's Taxonomy. Studies in Art Education. 26(1):41-50

Housen, A. (2002). "Aesthetic thought, critical thinking, and transfer." Arts and Learning Research Journal, 18, No. 1.

Housen, A and Yenawine, P. (2000-02). Visual Thinking Strategies Curriculum.Retrieved 31 August 2010 
from: http://www.vue.org.

Housen, A. and Yenawine, P. (2001). Guide to Museum Visits. New York: Visual Understanding in Education.

Nilson, C., Fetherston, C. and McMurray, A. (2013). Teachers' and Mothers' Perceptions of using Creative Arts to Develop Children's Potential for Critical Thinking. The International Journal of Arts Education. 7(1), 1-16.

Peterson, R. (2006). Crossing Bridges That Connects the Arts, Cognitive Development and the Brain. Journal for Learning Through the Arts. 1(1), 1-10.

Rowland, (2001). It's the thought that counts! Fostering student thinking in the classroom. University of Florida.

Wagner, T. (2005). Quality Education and Arts Education. Paper presented at UNESCO Asia-Pacific Regional Conference in Preparation for the 'World Conference on Arts Education' Seoul, Korea, November 23-25, 2005.

Yenawine, P. (2003). Jump Starting Visual Literacy. Thoughts on image selection. Art Education. 56(1).6-12. 